\title{
Sekuritisasi dalam Kerangka "R2P" dan Intervensi Kemanusiaan: Dilema Antara Legalitas dan Legitimasi
}

\section{Eric Hendra}

President University, Jakarta Kampus Jababeka, Cikarang 17550 erichendr@gmail.com

\begin{abstract}
The paper sets off by discussing security concept in IR and securitization process as well as new emerging norms in the frame of "R2P". Furthermore, this paper also tries to examine closer at legal, ethic also other dilemmas by entering the discourse of legality and legitimacy of humanitarian intervention by take a look at positivism and naturalism approaches. It is also tries to convey the discussion by elaborating the humanitarian intervention with traditional principles of just war and utilizing criteria of jus ad bellum and jus in bello. Eventually, it is inquiring the execution of the concept of R2P which is, supposedly, built upon the equivalent of state's basic right and responsibility and proviso it is so then why discrimination and double standard still crop up in implementing humanitarian intervention.

Keywords: Just War, Intervensi Kemanusiaan, Positivisme, Sistem Westphalia, Naturalisme

Abstrak

Artikel ini berangkat dari diskusi konsep keamanan dalam studi hubungan internasional dan proses sekuritisasi serta norma-norma baru yang muncul dalam kerangka "R2P". Selain itu, artikel ini juga mengkaji pada aspek hukum, etika juga dilema-dilema lain dengan masuk ke dalam diskursus legalitas dan legitimasi intervensi kemanusiaan dengan merujuk pada pendekatan positivisme dan naturalisme. Artikel ini juga mencoba mengelaborasi intervensi kemanusiaan dengan prinsip tradisional Just War dan jus ad bellum dan jus in bello. Pada akhirnya, artikel ini mempertanyakan pelaksanaan konsep R2Pyang seharusnya dibangun atas hak dasar negara yang setara, itulah mengapa kemudian diskriminasi dan standar ganda masih muncul dalam intervensi kemanusiaan.

Kata kunci: Just War, Intervensi Kemanusiaan, Positivisme, Sistem Westphalia, Naturalisme
\end{abstract}

\section{PENDAHULUAN}

Dalam konsep negara-bangsa moderen serta berdasarkan hukum internasional yang saat ini berlaku maka negara-negara memiliki kedaulatan bahkan dilindungi oleh norma non-interference dalam hal yang berkaitan dengan masalah dalam negerinya. Dalam perjalananya konsep dan norma ini bergeser seiring dengan perkembangan dalam hubungan antar negara serta berkembangnya aktor-aktor yang tidak lagi hanya terfokus pada aktor negara saja. Hal ini berkonsekuensi dengan tereduksinya norma-norma tradisional dari konsep negara-bangsa moderen tadi.

Tantangan utama datang dari kemunculan normanorma baru yang diperkenalkan pada decade 1990an dengan istilah kewajiban untuk melindungi atau lebih dikenal dengan konsep Responsibility to Protect "R2P". Norma ini pada awalnya dan terutama dipromosikan oleh negara-negarabarat, akan tetapi saat ini perkembangannya mulai meluas meskipun masih belum dapat dikatakan telah menjadi sebuah norma yang bersifat universal. Perkembangan ini juga didasari 


\section{Tabel 1}

\begin{tabular}{|c|c|c|c|c|}
\hline \multicolumn{5}{|c|}{ KONSEP KEAMANAN DAN ANCAMAN KEAMANAN } \\
\hline Konsep & Objek Rujukan & $\begin{array}{l}\text { Nilai yang } \\
\text { terancam }\end{array}$ & Sumber Ancaman & Bentuk Ancaman \\
\hline $\begin{array}{l}\text { Keamanan } \\
\text { Nasional }\end{array}$ & Negara & $\begin{array}{l}\text { Kedaulatan, } \\
\text { Integritas teritori }\end{array}$ & Negara Lain & Serangan Militer \\
\hline & Rejim & Kekuasaan & Oposisi, Pemberotak & \\
\hline Keamanan & Bangsa & Persatuan Nasional & Imigran & Genosida, Pembersihan \\
\hline Sosial & Kelompok sosial & Identitas & Budaya & Etnis \\
\hline Kemanan & Individu & Keberlangsungan & Negara, Kelompok, & Kriminalitas, \\
\hline Manusia & Manusia & Kualitas Hidup & Individu, Globalisasi & $\begin{array}{l}\text { Keterbelakangan, } \\
\text { Terorisme }\end{array}$ \\
\hline Keamanan & & & Pertumbuhan & Epidemik, Konflik, \\
\hline Lingkungan & & & $\begin{array}{l}\text { Penduduk } \\
\text { Habisnya Sumber Daya }\end{array}$ & Bencana Alam \\
\hline & $\begin{array}{l}\text { Ekosistem, } \\
\text { Spesies, Planet }\end{array}$ & $\begin{array}{l}\text { Keberlanjutan } \\
\text { Eksistensi }\end{array}$ & Manusia & $\begin{array}{l}\text { Pemanasan Global, } \\
\text { Polusi, Perusakan Alam }\end{array}$ \\
\hline
\end{tabular}

oleh semakin meningkatnya tuntutan akan perlunya norma-norma hak asasi manusia yang bersifat universal diterapkan dalam setiap pendekatan hubungan antar aktor, baik aktor negara maupun aktor bukan negara, di dalam hubungan internasional.

Berdasarkan norma "R2P" ini, negara akan kehilangan kedaulatannya jika negara tidak dapat dan tidak mau melindungi warga negaranya sendiri dimana dalam kondisi dan situasi demikian memberikan hak sekaligus kewajiban bagi negara-negara lain dan atau organisasi internasional untuk melindungi warga negara tersebut. Perlindungan ini termasuk, tetapi tidak selalu, pengerahan kekuatan militer atau intervensi militer serta membawa mereka yang bertanggung jawab untuk dituntut baik dibawah yuridiksi ekstra territorial atau yuridiksi universal. Akan tetapi "R2P" juga dapat mengambil bentuk tindakan yang tidak kontroversial seperti bantuan kemanusiaan atau jenis bantuan lainnya kepada korban.

Bentuk tindakan atau aksi ini seringkali dirujukan dengan istilah intervensi kemanusiaan. Meskipun pada perkembangannya intervensi kemanusiaan ini seringkali dipahami sebagai penggunaan kekuatan militer yang bersifat lintas batas (trans-boundary )yang bertujuan untuk menghentikan atau minimal mengurangi penderitaan manusia dari sebuah tindakan pemusnahan atau pembantaian. Sejak 1990an dan awal 2000an pembahasan mengenai intervensi kemanusiaan ini telah menarik perhatian banyak para ahli lintas bidang studi seperti Hukum Internasional, Ilmu Politik, Hubungan Internasional, etika bahkan filsafat.

Pada akhirnya PBB juga mengadopsi setelah merevisi gagasan seperti dari Komisi Internasional untuk Intervensi dan Kedaulatan Negara (ICISS) serta kewajiban untuk melindungi (R2P) dalam UN World Summit pada tahun 2005 dan disahkan juga oleh Dewan Keamanan PBB (UNSC). Meskipun intervensi kemanusiaan ini seringkali dalam prakteknya dibayangi atau bahkan tertutupi oleh 'perang global melawan terrorisme' (Roth, 2005) akan tetapi topik ini tetap menjadi fitur utama dan menarik dalam diskursus internasional.

\section{METODOLOGI}

\section{SEKURITISASI DAN "R2P"}

Jika kita membahas mengenai konsep "R2P" maka dengan sendirinya prinsip-prinsip yang melekat pada konsep tersebut tidak akan lepas dari pembahasan mengenai konsep keamanan. Dalam hal ini adalah pergeseran konsep keamanan dari satu bentuk ke bentuk lainnya atau secara konkrit adalah pergeseran dari keamanan nasional (umumnya merujuk pada pengentian kemanan negara) menjadi kemanan sosial atau manusia (societal and human security). Oleh 
karenanya, makalah ini akan diawali dengan pembahasan mengenai konseptualisasi keamanan secara singkat.

Sejak masa Perang Dunia ke II, kajian mengenai keamanan telah menempatkan konsep keamanan nasional atau negara sebagai hirauan utama dari banyak ilmuwan Hubungan Internasional, terutama didominasi oleh aliran pemikiran Realisme.Akan tetapi jika kita coba lebih mendalami lagi maka hanya sedikit sekali publikasi yang membahas mengenai konsep keamanan itu sendiri dibanding dengan tulisan-tulisan mengenai strategi dalam mencapai keamanan. Hans Morgenthau yang dianggap sebagai Bapak Realisme Klasik sangat sedikit sekali membahas mengenai konsep keamanan bahkan tidak ada dalam tulisannya yang mencoba mendefinisikan konsep keamanan itu sendiri.Mungkin yang paling mendekati dalam tulisannya mengenai konsep keamanan adalah pembahasan mengenai keamanan nasional yang didefinisikannya sebagai bagian yang terintegrasi dari teritori nasional dan institusi-institusinya. Dalam bagian lainnya ia juga menambahkan unsur "budaya" yang menekankan bahwa kelangsungan dari sebuah unit politik dalam identitasnya merupakan "irreducible minimum, the necessary element of its interests vis-à-vis other units" (Morgenthau, 1971: 219).

Sepertinya Arnold Wolfers adalah salah satu dari sedikit sekali ahli yang mencoba mendefinisikan keamanan dimana hingga saat ini definisinya masih dianggap kurang lebih sebagai sebuah standar atau rujukan. Ia menyatakan bahwa keamanan, dalam sebuah pengertian objektif, mengukur ketiadaannya ancaman terhadap nilai-nilai yang ada sedangkan dalam sebuah pengertian subjektif adalah tidak adanya rasa takut bahwa nilai-nilai tersebut akan diserang (Wolfers, 1962: 150). Dari definisi tersebut timbullah beberapa pertanyaan seperti nilai siapa yang terancam, nilai-nilai apakah itu, siapa yang mungkin menyerangnya, dan sebagainya.

Kebanyakan para peneliti perdamaian merasa tidak begitu nyaman dengan fokus eksklusif pada aspek militer jika membahas keamanan nasional, dan oleh karenanya, sejak beberapa dekade yang lalu mereka telah mencoba untuk mengembangkan konsep perdamaian, keamanan dan kekerasan yang lebih komperhensif. Baik Kenneth Boulding dengan konsep "stable peace" maupun Johan Galtung dengan "positive peace" nya telah memulai sebuah usaha untuk memperluas cakupan dari pengertian konsep keamanan. Mereka menyatakan bahwa untuk mendapatkan sebuah keamanan yang berjangka panjang dan pasti maka keamanan haruslah dibangun berdasarkan pada struktur perdamaian positif atau stabil.

Dari usaha awal untuk lebih mengembangkan dan memperluas pengertian keamanan seperti diatas tersebut, sepertinya pengembangan konsep keamanan yang lebih luas yang coba ditawarkan oleh Barry Buzan dalam bukunya People, States and Fear mendapat sebuah penerimaan yang cukup baik dari komunitas Hubungan Internasional. Buzan mencoba untuk memasukan dimensi-dimensi baru dalam konsep keamanan khususnya dimensi ekonomi (Buzan, 1983: 6).

Berangkat dari perkembangan konsep keamanan diatas serta merujuk pada pengertian sekuritisasi yang terkait erat dengan konstruksi sosial politik keamanan (Buzan, Waever, de Wilde, 1998) maka makalah ini mencoba untuk melihat lebih jauh bagaimana keamanan dapat dikonseptualisasikan keluar dari ruang lingkup tradisional dari keamanan nasional. Proses konseptualisasi ini didasarkan pada empat pertanyaan yang dimunculkan sebagai berikut:

a. Keamanan milik siapa? Pertanyaan ini adalah pertanyaan yang merujuk pada terminologi yang dimunculkan oleh Buzan dan kawan-kawan yaitu "referent objects" (negara, kelompok atau kolektivitas manusia selain negara, dan individu).

b. Keamanan apa? Pertanyaan ini tergantung pada jawaban pertama. Meskipun pada intinya pengertian keamanan dapat diartikan sebagai ketiadaan ancaman pada nilai yang berbeda akan tetapi milik siapa keamanan itu ditujukan akan memunculkan konotasi yang sangat berbeda.

c. Keamanan bagi siapa? Pertanyaan ini merujuk pada sumber ancaman dimana nilai-nilai yang berbeda 
akan dipersepsikan secara berbeda oleh aktor-aktor yang berbeda, contohnya ancaman struktural seperti pemanasan global.

d. Keamanan dari apa? Pertanyaan ini merujuk pada bentuk ancaman, apakah ancaman militer atau nonmiliter.

Uraian sekuritisasi dan konsep keamanan diatas dapat diformulasikan dalam tabel 1:

(Lihat tabel 1)

\section{HASIL DAN PEMBAHASAN}

\section{KEAMANAN NEGARA VERSUS KEAMANAN SOSIAL DAN MANUSIA}

Apa yang menjadi karakter pendekatan keamanan dari Hubungan Internasional tradisionaladalah menempatkan negara sebagai sentral atau fokus keamanan. Negara merupakan sebuah entitas sui generis seringkali digambarkan sebagai fitur metafisikal atau dipersonifikasikan sehingga ia diperlakukan seakanakan sebagai seorang individu (Hobbes, 1968: 227). Dimana aturan main dari sistem Wesphalian menjadi dasarnya yang menempatkan semua negara sebagai berdaulat tanpa melihat "nature" dari negara-negara tersebut serta melarang ikut campur dalam urusan dalam negeri negara-negara tersebut dengan menyatakan bahwa segala sesuatu yang terjadi di dalam batas territorial mereka maka itu diartikan sebagai "domaine reserve".

Keamanan nasional dalam konteks diatas, seringkali diartikan sebagai keamanan rejim yang berkuasa meskipun menempatkan warganya sebagai korban atau dalam keadaan bahaya. Bahkan aktivitas-aktivitas oposisional seringkali diberikan label sebagai ancaman bagi keamanan nasional (Bengio, 1998).Hingga dekade 1990-an, sejak berakhirnya perang dingin klaim-klaim seperti ini sangat jarang diperdebatkan di dunia internasional. Hingga terjadinya kejadian-kejadian kemanusiaan yang besar seperti perang di Balkan dan genosida di Rwanda yang mampu merubah pola dan kebiasaan tersebut yang akhirnya memunculkan perdebatan tentang kewajiban untuk melindungi (R2P).

Diawal 1990-an kita mengenal aliran pemikiran yang seringkali merujuk pada kajian-kajian yang dilakukan oleh Barry Buzan dan Ole Waever (Copenhagen School) yang mempromosikan perluasan ruang lingkup dan pengertian keamanan dalam kategori kolektivitas manusia selain negara seperti bangsa yang tidak memiliki negara (stateless nation) dan kelompok etnis atau agama. Kategori keamanan dalam pengertian ini biasanya lebih dikenal dengan istilah keamanan sosial (societal security). Secara definisi keamanan sosial ini diartikan sebagai kemampuan sebuah masyarakat untuk mempertahankan karakter dasarnya dibawah kondisi perubahan serta kemungkinan ancaman atau ancaman aktual (Buzan, 1993:23). Dengan demikian keamanan sosial baik secara langsung maupun tidak berkaitan dengan identitas yang dalam kajian teori Hubungan Internasional saat ini menjadi sebuah topik yang cukup hangat. Bahkan banyak para ahli juga menyatakan bahwa negara juga pada saat ini sedang menghadapi masalah identitas, dengan istilah yang mereka sering gunakan yaitu ontological security(Mitzen, 2006: 341-370).

Diantara banyak fenomena yang dikonstruksikan sebagai ancaman keamanan sosial antara lain adalah migrasi internasional, ekstrim atau ultra nasionalisme atau xenophobia (Bigo, 2002: 63-92). Apabila satu kelompok melihat keberadaan dan identitas kelompok lainnya sebagai ancaman dan mereka bertindak berdasarkan hal itu atau dengan kata lain telah terjadi dilema keamanan sosial, maka keamanan kelompok pertama tersebut diperoleh dengan ketidakamanan dari kelompok lainnya (Posen, 1993: 27-47). Lebih lanjut, jika usaha sekuritisasi tersebut berhasil maka hal ini dapat dijadikan justifikasi dalam sebuah pelanggaran luar biasa seperti pembantaian terhadap kelompok lawan atau bahkan pembersihan etnis atau genosida seperti yang terjadi dalam kasus Rwanda. Yang pada akhirnya memunculkan perdebatan akan perlunya kewajiban untuk melindungi (R2P).

Bahkan lebih jauh pada perkembangannya kewajiban untuk melindungi tidak hanya mencakup keamanan sosial akan tetapi juga dikaitkan pada keamanan manusia (Newman, 2001: 239-251). Istilah 
keamanan manusia (human security) pada awalnya diperkenalkan oleh UNDP dalam laporan pembangunan manusianya (human development reports) 1993 dan 1994.Didalam laporan tersebut dinyatakan bahwa konsep keamanan haruslah berubah dari sebuah penekanan ekslusif pada keamanan nasional menjadi sebuah penekanan yang lebih besar pada keamanan manusia, dari keamanan dengan persenjataan menjadi keamanan melalui pembangunan manusia, dari keamanan territorial menuju keamanan pangan, pekerjaan dan lingkungan (UNDP human development reports, 1993).

Konsep Negara Moderen, Kedaulatan dan R2P”

Sebagaimana konsep kewajiban untuk melindungi (R2P) akan berbenturan dengan konsep keamanan nasional, R2P juga mengalami benturan dengan sistem negara-bangsa moderen (Sistem Westphalian).

Persoalannya adalah apakah sistem Westphalian tersebut telah tersingkirkan secara keseluruhan dengan munculnya norma R2P atau masih tetap berlaku. Apabila sistem Westphalian tersebut sudah tidak valid lagi dalam menghadapi tantangan dan perubahan hubungan internasional, maka pertanyaannya kemudian adalah fitur-fitur apa yang berbeda dari sistem baru yang menggantikannya?

Perdamaian Westphalia pada tahun 1648 yang melahirkan perjanjian Osnabruck dan Munster, sebagai tanda berakhirnya perang 30 tahun dan 80 tahun di Eropa pada saat itu, merefleksikan pergulatan antara negara-negara Eropa yang berbentuk monarki pada saat itu dengan beragam otoritas saingannya seperti gereja katolik dan bangsawan feodal. Melalui perdamaian Westphalia, negara-negara tersebut telah mentransformasi Eropa ke dalam sebuah sistem negara atau yang oleh Hedley Bull disebut sebagai "anarchical society" (Bull, 1995: 65-71). Sistem negara ini didasarkan kepada pengakuan secara resiprokal atas kedaulatan masing-masing negara dan norma ini secara bertahap meluas menjadi sebuah norma yang lebih umum yaitu norma non-interference di dalam seluruh permasalahan domestik masing-masing negara termasuk masalah hak asasi manusia.

Dalam perkembangannya norma dari sistem negara ini pada akhirnya menjadi bagian dari hukum internasional yang dikodifikasi kedalam beberapa konvensi seperti seperti konvensi Montevideo 1933 mengenai hak dan kewajiban negara serta piagam PBB 1945. Inti dari kodifikasi tersebut adalah menguatkan hak-hak berdaulat dari negara-negara. Lebih jauh konvensi Montevideo bahkan memasukkan prasyarat sebuah negara yaitu harus memiliki penduduk permanen, teritori, pemerintahan serta kapasitas untuk melakukan hubungan dengan negara lain, atau dengan kata lain negara memiliki hak penuh untuk mempertahankan integritas dan kemerdekaannya serta mengorganisasikan dirinya sendiri sesuai dengan kepentingan nasionalnya dimana tidak ada negara lainnya yang memiliki hak untuk campur tangan dalam urusan internal dan eksternal suatu negara. Dapat disimpulkan sistem negara yang merujuk pada kodifikasi perdamaian Westphaliamenekankan bahwa teritori dari sebuah negara tidak dapat menjadi objek okupasi militer atau bentuk okupasi lainnya dari negara lain baik bersifat langsung maupun tidak langsung atau dengan motivasi apapun meski bersifat sementara (Grant, 1998: 403-458).

Sedangkan piagam PBB 1945 secara eksplisit mengkonfirmasi hak-hak kedaulatan negara seperti yang dinyatakan dalam pasal 2.1 yang menyatakan bahwa semua negara adalah sederajat dan oleh karenanya dalam pasal 2.4 mereka tidak diperbolehkan menggunakan kekuatan atau mengancam untuk menggunakan kekuatan terhadap kedaulatan dan integritas territorial satu sama lainnya kecuali dalam kasus membela diri baik secara individual maupun kolektif. Bahkan dalam pasal 2.7 Dewan Keamanan sekalipun tidak diijinkan untuk melakukan intervensi dalam hal-hal yang diangap sebagai juridiksi domestik setiap negara, kecuali perdamaian dan keamanan internasional terancam sebagaimana yang dinyatakan dalam Bab VII piagam PBB tersebut. Demikian juga dalam beberapa deklarasi yang diambil oleh Majelis Umum PBB sering menyisipkan dan mengelaborasi klausa-klausa mengenai prinsip non-intevention.

Pengertian negara berdaulat tentu tidaklah berarti semua negara selalu dapat bebas melakukan apa yang 
mereka sukai. Pada kenyataannya ukuran dan kekuatan sebuah negara juga menentukan siapa yang dapat melakukan apa terhadap yang lainnya. Diktum ini sudah terformulasikan sejak masa Thucydides bahwa yang kuat melakukan sesuai dengan kekuatan yang dimilikinya sedangkan yang lemah menerima apa yang harus mereka terima (Thucydides, 1972: 402), yang berarti bahwa negara kecil atau lemah dapat dipaksa oleh negara yang lebih kuat untuk melakukan apa yang mereka tidak inginkan.

Lebih jauh, meskipun demikian negara-negara kuat tersebut secara umum tetap masuk kedalam ikatan perjanjian internasional, yang pada gilirannya akan membawa mereka pada suatu jaringan kerjasama dan peningkatan kesadaran akan larangan dan kewajiban yang mereka harapkan juga mendapatkan komitmen dari negara lainnya. Hal inilah yang dikenal dengan istilah rejim internasional dimana seperangkat prinsip, norma, aturan serta prosedur pengambilan keputusan baik yang bersifat implisit maupun eksplisit berlaku dimana tujuan atau kepentingan dari aktor-aktor tersebut dapat terwadahi. Dengan kata lain, secara umum disepakati bahwa mereka secara keseluruhan memiliki kedaulatan (Krasner, 1982)

Apa yang menjadi permasalahan mengenai konsep kedaulatan adalah sesuatu yang tidak dapat diuraikan dengan mudah. Konvensi Montevideo mengatur pengakuan terhadap negara-negara sebagai suatu yang mutlak dan mengikat, yaitu status kenegaraan adalah suatu yang dapat diperoleh tetapi tidak dapat hilang. Apa yang dimaksud dalam hal ini adalah sebuah negara mungkin saja bisa menjadi negara kuasi (quasi-state), baik dalam pengertian sebagai sebuah negara yang tidak memiliki kapasitas pemerintahan aktual maupun dalam pengertian institusi non-negara yang melakukan fungsi-fungsi layaknya sebuah negara (Deutsch, 1986: 209-222). Untuk pengertian negara kuasi pertama merujuk pada pengakuan formal atas kedaulatan oleh negara lain atau organisasi internasional, yaitu pengertian yang juga dikenal dengan kedaulatan eksternal yang dengan sendirinya akan melekat atas pengakuan kedaulatan tersebut prinsip non-interference dalam masalah dalam negerinya sesuai dengan hukum internasional yang berlaku. Sedangkan pengertian yang kedua merujuk pada internal sovereignty atau dalam pengertian kendali aktual atau kontrol sebenarnya.

Alasan mengapa negara-kuasi tetap diakui adalah sitem internasional telah berkembang dan mengesampingkan perbedaan diantara negara-negara dan memperlakukan mereka tidak hanya sebagai unit tetapi sebagai sesuatu yang permanen yang seiring dengan tatanan sistemik (Waltz, 1979: 66-67). Konsekuensi yang muncul dari perkembangan sistem internasional seperti ini adalah tidak banyak negara dapat dianggap sebagai negara gagal (fail states) dikarenakan negara lainnya berpura-pura menganggap negara-negara tersebut tidak gagal. Padahal sesungguhnya negara-negara kuasi tersebut secara jelas tidak memiliki kemampuan untuk melindungi warga negaranya sendiri dan dari sinilah rationale bagi R2P muncul dan berkembang. Disamping itu perkembangan kekuatan globalisasi juga telah membawa prinsip dan konsep kedaulatan sebagai sesuatu yang dipertanyakan dan dianggap sampai pada hal-hal tertentu sebagai suatu yang tidak relevan, khususnya jika dikaitkan dengan kedaulatan teritorial.

Berangkat dari latar belakng diatas tidaklah mengherankan jika norma-norma baru seperti kewajiban untuk melindungi ( $R 2 P$ ) menjadi mengemuka khususnya setelah berakhirnya masa perang dingin. Perdebatan mengenai R2P sudah dimulai sejak pertengahan dekade 1990-an. Mungkin salah satu yang menjadi manifestasi perdebatan itu adalah publikasi buku yang berjudul Sovereignty as Responsibility karya Francis Deng. Ia berargumentasi bahwa didalam sebuah kedaulatan seharusnya juga melekat kewajiban atas rakyatnya. Lebih jauh ia mengatakan bahwa bersumber dari kewajiban inilah seharusnya legitimasi sebuah pemerintahan diperoleh (Deng et.al, 1996: 32)

Menanggapi hal ini serta mempertimbangkan kontroversi-kontroversi yang terjadi diseputar intervensi kemanusiaan di Somalia, Bosnia, Kosovo dan di tempat lainnya, Sekjen PBB saat itu, Kofi Annan dalam pidatonya didepan Majelis Umum PBB meminta sebuah perencanaan untuk aksi dalam 
mengantisipasi tragedi-tragedi kemanusiaan dimasa yang akan datang. Permintaan ini direspon oleh Kanada yang membentuk sebuah komisi independen yang kemudian kita kenal dengan International Commission on Intervention and State Sovereignty (ICISS). Komisi ini kemudian memberikan laporan pada bulan Desember 2001 yang berisi dua prinsip dasar:

a. Bahwa atas kedaulatan sebuah negara melekat kewajiban, dan kewajiban utamanya adalah melindungi orang-orang yang berada didalam negara tersebut.

b. Dimana sebuah penduduk mengalami tragedi yang serius sebagai akibat dari perang saudara, pemberontakan, penindasan, atau kegagalan negara (state failure) serta negara dipertanyakan kemauannya atau kemampuannya untuk menghentikan tragedi itu maka prinsip non-intervention berubah menjadi kewajiban internasional untuk melindungi (ICISS, 2001: xi).

Laporan tersebut cukup eksplisit dalam kaitannya dengan sesuatu kejadian yang extraordinary dan exceptional dimana intervensi internasional dapat dilakukan. Tindakan intervensi tersebut dapat dilakukan baik dikarenakan sebagai akibat dari situasi yang dikarenakan oleh tindakan negara, pengabaian negara atau negara gagal (failed state). Akan tetapi lebih jauh tindakan intervensi tersebut haruslah memenuhi kriteria "just war" yang berkaitan dengan diskursus mengenai "right intention, last resort, proportional dan memiliki kemungkinan yang besar untuk berhasil”. Akhirnya, sebuah "just war" hanya dapat dilakukan oleh aktor yang memiliki otoritas yang sah, yang dalam banyak kasus merujuk pada Dewan Keamanan PBB (UNSC).

Dari semua uraian diatas maka dapatlah kita melihat bahwa telah terjadi pergeseran setidaknya sedikit diluar dari yang selama ini berlaku yaitu prinsip-prinsip Westphalian menuju kearah pembentukan sebuah tatanan dunia baru yang mungkin banyak menyebutnya sebagai "Cosmopolis" dimana hak-hak kedaulatan dari negara tereduksi oleh hak asasi yang bersifat universal. Dari hanya sekedar sebuah pemikiran yang dahulu dianggap sebagai sesuatu yang utopian, norma kewajiban negara untuk melindungi warganya, yangmana jika tidak dipenuhi maka akan berkonsekuensi terhadap hak-hak kedaulatannya, telah mengarah kearah yang lebih konkrit.

\section{LEGITIMASI DAN LEGALITAS INTERVENSI KEMANUSIAAN}

Salah satu permasalahan yang seringkali dihadapi dalam hal intervensi kemanusiaan adalah pertanyaan mengenai legalitas dan atau legitimasi dari aksi atau tindakan tersebut. Pertanyaan pertama berkaitan dengan itu adalah apakah perbedaan dari dua hal tersebut dan kemudian kita akan dihadapkan pada pertanyaan lanjutan seputar apa dasar dari legalitas tadi serta dasar apa yang membuat sebuah intervensi kemanusiaan dapat dikatakan valid (legitimate). Dalam beberapa kasus permasalahan ini menjadi perdebatan tersendiri karena biasanya masuk pada ranah hukum internasional.

\section{POSITVISME, NATURALISME DAN "BELLUM JUSTUM"}

Untuk menjawab pertanyaan diatas maka makalah ini akan membahas mengenai dua dasar pemikiran atau pendekatan dalam studi hukum, baik internasional maupun nasional, yaitu positivisme dan naturalisme. Positivisme dalam konteks legal sulit untuk membedakan antara legalitas dan legitimasi dan biasanya menganggap legitimasi sebagai suatu yang metafisik dan mendasari argumennya bahwa sesuatu hanya dapat dianggap ilegal jika hukum yang berlaku menyatakan bahwa tindakan tersebut dilarang, meskipun kadangkala ada situasi dimana membuka kemungkinan bahwa sesuatu dapat secara umum dianggap tidak sah (illegitimate) sebelum dibuat menjadi ilegal (Nardin, 1998: 17-35).

Kalau kita melihatnya secara faktual yang dimaksud dengan prinsip "nullum crimen, mulla poena sine lege" diatas, sebenarnya juga sangat tidak jelas khususnya jika kita melihat bahwa seorang diktator yang jahat sekalipun berada pada posisi yang dapat mengeluarkan peraturan atau undang-undang yang membuat tindakan mereka menjadi sangat legal 
meskipun sebenarnya dapat jadi apa yang mereka lakukan secara moral sebenarnya melanggar atau tidak dapat diterima. Banyak contoh dari kasus diatas, seperti apa yang dilakukan oleh Militer Junta di Myanmar, Mesir saat ini atau pengalaman sejarah seperti Uni Soviet dibawah Stalin atau Jerman dibawah Hitler.

Di lain pihak, kita juga menemukan bentuk-bentuk lain dari pendekatan atau perspektif hukum natural, dimana menurut aliran naturalisme ini tindakantindakan tertentu pada hakekatnya melekat nilai benar atau salah, baik atau jahat dengan sendirinya, tanpa melihat apakah hal tersebut didukung oleh aturan atau undang-undang yang berlaku ataupun tidak (Boyle, 1993: 112-135). Lebih jauh lagi bahkan salah satu aliran dari naturalisme ini mendasari pendapat mereka, mengenai norma-norma tersebut diatas, dari hukum atau aturan yang berasal dari Tuhan yang merupakan kehendak-Nya yang diturunkan melalui wahyu (Cartwright, 1993: 270-296). Meskipun secara umum aliran ini biasanya diatributkan pada Islam akan tetapi tiga agama samawi yang bersumber dari Ibrahim biasanya juga sering mendasari pandangan mereka atas pewahyuan Tuhan ini.

Meskipun ketiga agama samawi ini mengakui validitas sepuluh perintah Tuhan (Ten

Commandmens) yang diwahyukan kepada Nabi Musa, tetapi ketiga agama ini juga memiliki sumber wahyu lainnya dan lebih jauh lagi ketiga agama ini memiliki perselisihan sektarian mengenai otoritas sumbersumber wahyu yang berbeda dan juga interpretasinya. Sebagai contoh umat islam menganggap hukum syariah sebagai kehendak Tuhan dan merupakan ipso facto yang lebih tinggi daripada hukum biasa akan tetapi diantara mereka masih terjadi perselisihan mengenai pengertian syariah itu sendiri disamping sejauh mana dapat diinterpretasikan. Hal yang sama juga berlaku pada umat katolik dengan dogma "apostolic succession” nya yang juga menempatkan supremasi keilahian diatas hukum sekular atau dengan kata lain menempatkan otoritas gereja diatas otoritas sekular seperti negara.

Jadi dapat dikatakan bagi sebagian pemikiran naturalisme perbedaan antara yang benar dan yang salah, yang baik dan yang buruk lebih bersifat aksiomatis. Akan tetapi pembedaan yang bersifat aksiomatis ini juga dapat dilihat dari deklarasi kemerdekaan Amerika Serikat 1776 "we hold these truths to be self-evident" meskipun pada faktanya tidak semua kebenaran dapat dijadikan self-evident. Contohnya para pendiri yang menulis deklarasi kemerdekaan tersebut terjadi ketidaksepakatan diantara mereka mengenai masalah perbudakan meskipun didalam deklarasi yang mereka tulis secara eksplisit menyatakan bahwa seluruh manusia diciptakan sederajat (Freeling, 1972:81-93). Dari apa yang dijabarkan diatas tampaknya kita harus dapat membedakan antara legalitas berdasarkan hukum dan legitimasi berdasarkan norma-norma etika.

Dari sini kita mencoba untuk melihat apa dasar legal bagi implementasi intervensi kemanusiaan. Ada beberapa sumber hukum yang dapat kita rujuk baik hukum internasional maupun konsep seperti opinio juris dan jus cogens. Perjanjian hukum internasional seharusnya adalah dasar yang paling ideal bagi pengimplementasian intervensi kemanusiaan, akan tetapi sampai saat ini belum ada otorisasi internasional kecuali seperangkat aturan yang bersumber pada sistem Westphalian seperti yang termanifestasi dalam pasal 2.4 dan 2.7 piagam PBB.

Untuk menjustifikasi intervensi kemanusiaan kita dapat melihat kepada tradisi just wardimana kriteria dari just war secara umum dapat dibagi kedalam dua aturan yaitu aturan yang mengatur hak sebelum berperang atau dikenal dengan konsep jus ad bellum dan hukum perang yang dikenal dengan jus in bello (Hallett, 1999: 283-293). Sebagaimana dapat dilihat pada table dibawah ini.

\begin{tabular}{lll}
\hline \multirow{2}{*}{ Konsep } & PRINSIP-PRINSIP "JUST WAR" \\
& Sebab dan Tujuan yang benar & Otoritas yang benar \\
& Otoritas yang benar & Imunitas bagi sipil \\
Kriteria & Pilihan terakhirProporsionalitas & Proporsionalitas \\
& Kemungkinan berhasil & Target yang dilarang \\
& & Senjata yang dilarang \\
\hline
\end{tabular}

Tradisi just war juga dapat dilihat dari tiga agama samawi yang diuraikan diatas. Pemikiran agama Kristen 
yang bersumber kepada Thomas Aquinas (1225-1274) dalam bukunya Summa Theologia memformulasikan just war dapat dilaksanakan dengan menerapkan tiga hal, yaitu pertama hanya pemerintah yang berdaulat yang dapat melaksanakan perang karena hal ini bukanlah urusan individu dalam mendeklarasikan perang dan dikarenakan ini adalah urusan otoritas yang berdaulat maka menjadi kewajibannya untuk melindungi wilayahnya baik terhadap gangguan internal maupun musuh eksternal. Kedua, alasan pendeklarasian perang haruslah tepat seperti ketika diserang atau jika menyerang dengan alasan yang tepat pula. Ketiga, harus mempunyai tujuan yang benar dalam mendeklarasikan perang karena mungkin saja perang dideklarasikan oleh otoritas yang legitimate dikarenakan alasan yang tepat akan tetapi tujuannya salah atau menyimpang. Begitu juga dengan Judaisme dan Islam dalam memandang just war.

\section{ANTARA REALITA DAN IDEALITA: DILEMA HAK DAN KEWAJIBAN}

Ada dua dilemma besar yang muncul dalam setiap pembahasan konsep kewajiban untuk melindungi dan intervensi kemanusiaan. Tetap menjadi suatu perdebatan jika kita mempertanyakan apakah hak untuk melaksanakan intervensi kemanusiaan baik dipandang secara legal maupun etika sama dengan sebuah kewajiban untuk melakukan intervensi kemanusiaan? Atau ini hanya sebuah hak bagi negaranegara secara bebas untuk melakukannya atau tidak. Jika jawabannya adalah yang pertama maka sepertinya tidak akan banyak negara mau memiliki hak atau kewajiban tersebut. Akan tetapi jika tidak maka mereka yang mau melakukan intervensi akan dihadapkan pada pilihan mengenai kapan dan dimana melakukan intervensi dan berdasarkan pada kriteria apa untuk membuat pilihan ini?

Analogi akan coba dibangun ntuk menjawab hal ini. Apabila hak "A" untuk melakukan intervensi didasarkan pada kegagalan negara "B" dalam melaksanakan kewajibannya seperti melindungi warganya maka nampaknya akan logis apabila "A" mengasumsikan ini sebagai kewajibannya juga secara pararel (Pattison, 2008: 262-283). Akan tetapi di lain pihak hal ini juga akan menimbulkan sebuah masalah baru yaitu biasanya "A" adalah masyarakat atau komunitas internasional yang dengan demikian tindakan "A" akan dilihat sebagai tindakan bersama (collective action). Dikarenakan komunitas ini bukanlah suatu aktor tunggal tetapi terdiri dari aktor-aktor individual (utamanya negara) yang menginginkan tindakan intervensi tersebut diambil (sebagai public good) tetapi mereka juga lebih suka negara lain yang melakukannya atau dapat dikatakan sebagai "free riding" atas usaha yang aktor lain. Dan pada gilirannya jika kebanyakan aktor lebih cenderung kearah ini maka public good tidak akan dihasilkan (Kaul et.al, 1999: 2 19).

Salah satu cara untuk mengatasi situasi diatas adalah dengan menetapkan kewajiban berdasarkan kapasitas. Karena tidak mungkin sebuah kewajiban dilaksanakan jika kewajiban itu melebihi kapasitasnya. Dalam hal ini, secara logika, seharusnya negara-negara yang memiliki kapasitas militer besarlah yang seharusnya mengemban tugas tersebut.Sebagaimana pribahasa yang mengatakan "beban terberat" seharusnya diberikan pada mereka yang memiliki pundak terbesar" atau negara mana yang memiliki hak istimewa seharusnya juga mengemban kewajibankewajiban khusus. Kedua kriteria yang diuraikan diatas nampaknya akan tepat jika diberikan diantaranya kepada "the big five" atau anggota permanen Dewan Keamanan PBB yang juga kebetulan adalah military great powers (Reinold, 2011: 61-87).

Terlepas dari bagaimana seharusnya hak dan kewajiban tersebut didistribusikan, maka sepertinya tidak mungkin supply of power untuk melakukan intervensi akan sama dengan demand, khususnya jika kita memahami intervensi kemanusiaan sebagai sebuah tindakan yang bersifat pengorbanan. Jika kita membahas lebih jauh lagi masalah intervensi kemanusiaan sepertinya adalah hal yang cukup jelas dimana ada beberapa negara yang tidak akan pernah dapat menjadi target diberlakukannya intervensi kemanusiaan, meskipun mungkin negara-negara tersebut memiliki catatan buruk atas pelanggaran hak 
asasi manusia. Sebagaimana tidak ada satupun negara di dunia yang ingin memprovokasi terjadinya perang nuklir hanya dengan alasan untuk menolong orang asing.

Negara-negara pemilik senjata nuklir mungkin akan tenang dan dapat memastikan diri mereka tidak akan menjadi target dilaksanakannya intervensi kemanusiaan. Sebagai tambahan juga negara-negara pemegang hak veto di Dewan Keamanan PBB juga akan merasa tenang bahwa mereka tidak akan mengalami intervensi kemanusiaan dinegara mereka karena mereka dapat mencegah resolusi sebagai landasan legal dengan melakukan veto di Dewan Keamanan PBB. Negaranegara sekutu formal dari negara-negara Barat, seperti anggota NATO, EU atau negara-negara seperti Jepang, Korea Selatan, Australia, Selandia Baru akan dapat dipastikan akan mendapatkan perlindungan terhadap intervensi tersebut. Jadi sepertinya target yang paling potensial dilakukannya intervensi kemanusiaan sepertinya hanya jadi milik negara-negara berkembang di Asia-Afrika atau negara-negara periphery di Eropa seperti di wilayah Balkan atau Caucasus delimitation. Kondisi seperti ini adalah kondisi yang bagi banyak aktor dilihat sebagai penerapan standard ganda.

\section{KESIMPULAN}

Kita telah melihat bahwa ada pergeseran yang menjauh dari tatanan dunia yang berdasarkan pada sistem Westphalian, dengan normanya mengenai kedaulatan negara yang bersifat absolut serta prinsip non-intervention terhadap permasalahan dalam negeri sebuah negara yang merujuk pada konsep keamanan nasional (biasanya berkonotasi kemanan negara), menuju kesebuah tatanan internasional baru yang lebih mengarah kepada tatanan cosmopolitan dimana intervensi dapat dilakukan demi norma-norma lainnya dalam melindungi manusia, seperti hak asasi manusia dan keamanan manusia.

Meskipun masih jauh dari kesepakatan universal yang dapat diterima oleh semua masyarakat internasional akan tetapi bagi negara-negara yang mendukung norma baru ini seakan mendapatkan landasan mereka, meski secara bertahap, serta prinsip- prinsip umum mengenai kedaulatan sebagai kewajiban serta R2P nampaknya sudah hampir dapat diterima secara umum, setidaknya secara retorikal, meskipun aplikasi aktualnya masih sering terbentur dengan ketidaksepakatan baik dari landasan hukum dalam melihat masalah ini yaitu perbedaan antara perspektif positivism dan naturalisme dalam menentukan apakah sebuah tindakan intervensi memiliki dasar legalitas atau dapat dianggap sebagai sebuah tindakan yang legitimate.

Lebih jauh lagi intervensi kemanusiaan ini juga menjadi lebih kompleks ketika kita harus mempertanyakan pelaksanaanya berdasarkan prinsipprinsip "just war" baik dari konsep jus ad bellum maupun jus in Bello. Dalam penerapannya juga, intervensi kemanusiaan harus dihadapkan pada banyak dilema, terutama soal bagaimana melihat dan menerapkan kewajiban dan hak serta implementasinya sebagai suatu produk kolektif. Disamping itu juga dengan segala kriterianya penerapan intervensi kemanusiaan juga akan terbentur dengan siapa yang memiliki hak lebih untuk melakukan dan mencegah terjadinya intervensi atau dengan kata lain standar ganda sepertinya tidak dapat dihindari dalam sistem yang masih menekankan pada power exercise dan power relations sebagaimana diaminkan oleh aliran pemikiran realisme dalam studi Hubungan Internasional.

\section{BIBLIOGRAFI}

Bengio, Ofra. 1998. Saddam's World: The Political Discourse in Iraq, Oxford: Oxford University Press

Bigo, Didier. 2002. Security and Immigration: Towards a Critique of the Governmentality of Unease, Alternatives, vol.27, no.1, hal 6392

Boyle, Joseph. 1993. Natural Law and International Ethics, di David R. Mapel \& Terry Nardin (eds.), Tradition in International Ethics, Cambridge: Cambridge University Press, 112-135

Bull, Hedley.1995. The Anarchical Society: A Study of Order in World Politics, $2^{\text {nd }}$ ed., Houndmills, Basingstoke: Macmillan, 65-71

Buzan, Barry, Ole Waever \& Jaap de Wilde. 1998. Security: A New Framework for Analysis, Boulder: Lynne Rienner

Buzan, Barry, Ole Weaver, Morten Kelstrup \& Pierre Lemaitre. 1993. Identity Migration and the New Security Agenda in Europe, London: Pinter, 23

Buzan, Barry. 1983. People, State and Fear: The National Security Problem in International Relations, Brighton: Wheatsheaf Books, 6 Cartwright, Michael G. 1993. Biblical Argument in international 
Ethics", di David R. Mapel \& Terry Nardin (eds.), Tradition in International Ethics, Cambridge: Cambridge University Press, 270296

Deng, Francis M, Sadikiel Kimaro, Terrence Lyons, Donald Rothchild \& William Zartman.1996. Soverignty as Responsibility: Conflict Management in Africa, Washington DC: Brookings Institution, 32

Deutsch, Karl W. 1986. State Functions and the Future of the State, International Political Science Review, vol.7, no.2, 209-222

Freeling, William W. 1972. The Founding Fathers and Slavery, American Historical Review, vol.77, no.1, 81-93

Grant, Thomas D. 1998. Defining Statehood: The Montevideo and its Discontents, Columbia Journal of Transnational Law, vol.37, no.2, 403-458

Hallett, Brien. 1999. Just War Criteria, di Lester Kurtz (ed.), Encyclopedia of Violence, Peace and Conflict, San Diego Academic Press, vol.2, 283-293

Hobbes, Thomas.1968. Leviathan, Harmondsworth: Penguin Books, 227

International Commission on Intervention and State Sovereignty (ICISS).2001. The Responsibility to Protect: Report of International Commission on Intervention and State Sovereignty, Ottawa: International Development Research Centre, xi

Kaul, Inge, Isabelle Grunberg \& Marc A. Stein. 1999. Defining Global Public Goods, di IngeKaul, Isabelle Grunberg \& Marc A. Stein (eds.) Global Public Goods: International Cooperation in $21^{\text {st }}$ Century, Oxford: Oxford University Press, 2-19

Krasner, Stephen (ed.). 1982. International Regimes, Ithaca, NY: Cornell University Press

Mitzen, Jennifer. 2006. Ontological Security in World Politics: State Identity and the Security Dilemma, European Journal of International Relations, vol.12, no.3 hal. 341-370

Morgenthau, Hans J. 1971. Politics in the Twentieth Century, Chicago, IL: Universityof Chicago Press,219

Nardin, Terry. 1998. Legal Positivism as a Theory of International Society di David R. Mapel \& Terry Nardin (eds.), International Society: Diverse Ethical Perspectives, Priceton, NJ: Princeton University Press, 17-35

Newman, Edward. 2001. Human Security and Constructivism, International Studies Perspectives, vol.2, no.3, 239-251

Pattison, James. 2008. Whose Responsibility to Protect?: The Duties of Humanitarian Intervention', Journal of Military Ethics, vol.7, no.4. 262-283

Posen, Barry P. 1993. The Security Dilemma of Ethnic Conflict, Survival, vol.35, no.1, 27-47

Reinold, Theresa. 2011. The United States and the Responsibility to Protect: Impediment, Bystander, or norm Leader?, Global Responsibility to Protect, vol.3, no.1, 61-87

Roth, Kenneth. 2005. War in Iraq: Not a Humanitarian Intervention," di Richard Ashby Wilson (ed.), Human Rights in the 'War on Terror, Cambridge: Cambridge University Press, 143-156

Thucydides. 1972. The Peloponnesian War, Harmondsworth: Penguin, hal. 402

UNDP Human Development Reports, 1993, www.undp.org/hdro/ e93over.htm, diunduh pada 8 Oktober 2013

Waltz, Kenneth. 1979. Theory of International Politics, Reading, MA: Addison-Wesley, 66-67
Wolfers, Arnold. 1962. National Security as an Ambiguous Symbol, di Arnold Wolfers, Discord and Collaboration Essays on International Politics, Baltimore, ML: John Hopkins University Press, 150 